Fluoridation

\section{Reluctant ban in Scotland}

BоTH sides in the battle over fluoridation of domestic water supplies were claiming partial victory last week after the first test case on the matter in the United Kingdom.

Lord Jauncey ruled in the Edinburgh Court of Session that it was beyond the powers of Strathclyde Regional Council to fluoridate water supplies, as it had planned to do, but accepted that one part per million of fluoride in water reduced dental decay and had no significant adverse effect on health. Mr P. Clavell Blount of the National Anti-Fluoridation Campaign said he was delighted that Lord Jauncey had ruled against fluoridation; the council, on the other hand, was "pleased" that fluoridation had been vindicated as harmless.

The petition to prevent the council from fluoridating water supplies was brought by Mrs Catherine McColl, a 69-year-old pensioner from Glasgow, who describes fluoride as "a horrible poison". The hearing, which started in September 1980, was lasted for 204 court days. The council brought an impressive range of expert witnesses to argue for the virtues of fluoridation and to refute the alleged link with cancer. Mrs McColl, who was conspicuous by her absence after the first day of the hearing, relied on US anti-fluoridationists Dr Dean Burk and Dr John Yiamouyannis.

The 120,000-word judgement hinged on the interpretation of the Scottish Water Acts of 1946 and 1980, which enjoined the water"'. Lord Jauncey accepted that it was unlikely that parliament had intended in pressive". lation. should be needed. the longest in Scottish legal history and water authorities to prove "wholesome

1946 that water supplies should serve as convenient means of achieving a beneficial effect on health of consumers. Some consumers would not be of an age to benefit from fluoride (or - like Mrs McColl have no teeth) and their freedom of choice would necessarily be restricted.

Lord Jauncey went out of his way to describe Dr Burke as "rambling and evasive", while Dr Yiamouyannis "allowed his hostility to obscure his scientific judgement". The evidence for excess cancer deaths linked to water fluoridation was, said the judge, "vague and unim-

A spokesman for Strathclyde Regional Council said it was only a matter of time before fluoridation was introduced: "we may have lost the battle but we will win the war". The council is asking for talks with Mr George Younger, Secretary of State at the Scottish Office, seeking new legis-

The more important implications of the case will first arise south of the Scottish border, where more than 10 per cent of the population already drinks artificially fluoridated water. English and Scottish law in this area are substantially similar, and there will now be pressure on local authorities in England and Wales to cease adding fluoride to water supplies. The Law Society says that a second test case for England and Wales is now on the cards, but the most serious question is whether the British government and parliament will have the stomach for new legislation if it

Tim Beardsley

\section{Margaret Thatcher, FRS by narrow vote}

BY a slender majority, the Fellows of the Royal Society decided last week that the Rt Hon. Mrs Margaret Thatcher "has done much to strengthen the cause of science in the United Kingdom" and so should be elected to join their ranks. Those angered by the citation failed by only a few votes to stop her election.

The election took place under a special statute of the society that allows its governing body, the council, to nominate persons who "have rendered either conspicuous service to the cause of science or are such that their election would be of signa benefit to the society". Opposition to Mrs Thatcher's fellowship centred on the view of some fellows that her service to the cause of science was conspicuous mainly by its absence and that ceremony should be cas aside in memory of shrinking university research and absent overseas students. But, when it came to the election last Thursday, just over the necessary two-thirds majority of the fellows present voted for Mrs Thatcher.

She joins Harold Macmillan and Sir
Harold Wilson in being elected FRS while Prime Minister. Wilson's election, while Society, caused a good deal of acrimony and opposition. There was a feeling thereafter that no further attempts to elect serving prime ministers should be made. Why the current council under its president, Sir Andrew Huxley, chose to risk nominating Mrs Thatcher is not clear. Having done so, the fellows are said to have been warned by Huxley that to reject her would be to do the society grave damage.

Last week's election meeting was said to have been much more sizeable and emolast of which was in 1976, when Sir Karl Popper was elected. Because there was no election of a fellow under the statute last year, a second election was allowed this year - David Attenborough, the film, maker best known for Life on Earth. It is uncertain if the few votes cast against his election were from an anti-television lobby or from fellows who thought they were opposing Mrs Thatcher. Peter Newmark Lord Blackett was president of the Royal tional than is usual for such occasions, the
European research

\section{Science council plans big}

Brussels

SCIENCE ministers of the European Community last week agreed that Community spending on scientific research should be increased. But, with the coffers empty and a budgetary crisis building up, will the money materialize?

Speaking after the science ministers' council meeting in Luxembourg, chairman Heinz Riesenhuber, the West German federal research minister, announced "we've agreed on the need to increase funding, but how this is to be done goes beyond our competence"'. Present spending on research and development accounts for around 2 per cent of the European Community budget of 25 million ECU (one European Currency Unit $=£ 0.58$ ). Research commissioner Etienne Davignon is pushing for a doubling of research spending to 4 per cent of the budget by next year.

Other achievements of the meeting, Riesenhuber explained, were the endorsement of a Commission proposal for a fouryear "framework programme" for research and development, and enthusiastic approval for Esprit, the programme for research in information technology. But "financial strains"' made it im. possible to give definite commitments on the asked-for 3,750 million ECU for the framework programme or the $\mathbf{7 5 0}$ million ECU for Esprit, the German minister said.

The monetary crisis is to be tackled in Athens on 5 December at the next summit meeting of European Community leaders. They will be looking for a way of curbing excessive farm spending and at the same time increasing support for other projects. Since this brings into question the structure of the controversial Common Agricultural Policy, and since some countries do not agree that the overall community budget should be increased, the summit could well end in deadlock.

The science ministers meet soon after the December summit, and no decisions to begin new projects or increase spending on existing ones can be expected before the hoped-for budget restructuring. And in this light, says a Commission official, "the Davignon line of gathering seemingly anodyne undertakings from member states to support scientific programmes without specific financial commitments could prove to be a very clever move"'.

If a new budget is agreed at the December summit, finance ministers will have just three weeks to adopt the 1984 financial scheme. And, says the Commission official, "if they skip research and development programmes, or sharply reduce asked-for financing, they could be in big trouble with a European Parliament entering its electoral period"'.

Geert Linnebank 